\title{
EPIDEMIOLOGY OF THE PREVALENCE OF PHENOTOPIC SIGNS UNDIFFERENTIATED CONNECTIVE TISSUE DYSPLASIA SYNDROME IN WOMAN WITH MISCARRIAGES
}

DOI: 10.36740/WLek202104112

\author{
Tunzala V. Ibadova, Volodymyr V. Maliar, Vitalii V. Maliar, VasyI V. Maliar \\ UZHHOROD NATIONAL UNIVERSITY, UZHHOROD, UKRAINE
}

\begin{abstract}
The aim: Study of the relationship between cervical insufficiency and dysplastic stigma in miscarriages.

Materials and methods: 80 pregnant women were examined at 23-27 weeks of gestation.) Group I included 40 pregnant women with the threat of premature birth, with habitual miscarriage and correction of cervical insufficiency (CI) by using pessary in the anamnesis. Group II consisted of 20 pregnant women with the threat of premature birth and correction of $\mathrm{Cl}$ by using pessary without the burden of habitual miscarriage, the control group of 20 almost healthy pregnant women.

Results: The studies revealed phenotypic signs of dysplastic stigmatization in $39(97.5+2.5 \%)$ pregnant women of group I, in $18(90.0+6.9 \%)$ group II and in 4 (20.0 + 9.2\%) control, which indicates a high prevalence of connective tissue dysplasia in women with $\mathrm{Cl}$, which also has a laboratory reflection in the form of increased excretion per day of oxyproline and a decrease in total glycosaminoglycans in both groups at risk of preterm birth.

Conclusions: The most common gestational complication in women with connective tissue dysplasia is the risk of premature birth. Improving existing and finding new diagnostic and therapeutic measures for women with UDCTD will reduce the risk of preterm birth.
\end{abstract}

KEY WORDS: UDCTD, preterm birth, pregnancy, glycosaminoglycans, oxyproline, dysplastic stigmatization

Wiad Lek. 2021;74(4):880-883

\section{INTRODUCTION}

The urgency of the problem of miscarriage in women with undifferentiated forms of connective tissue dysplasia is primarily due to the high prevalence that occurs in the general population up to $80 \%$ [1]. Miscarriages is the most common complication of the gestational process. Babies born at 23-27 weeks of gestation cause up to $50 \%$ perinatal mortality.

One of the significant factors in the genesis of prematurity is the syndrome of undifferentiated connective tissue dysplasia (UDCTD), which in women with cervical insufficiency (CI) of unknown origin is about $30 \%$, and the frequency of premature birth (PB) with CI correction reaches $30 \%[2,3,4]$. The main causes of $\mathrm{PB}$ in this case are rupture of membranes, chorioamnionitis, eruption of the suture on the cervix. It is known that in the human body connective tissue performs a structural, retaining, supporting, mechanical, homeostatic and immunological function[5,6,7].

Abnormal connective tissue structure in women with systemic tissue dysplasia is closely associated with disruption of both collagen synthesis and metabolism and changes in biodegradation. At defects of structure of collagen, elastin, glycopeptides, proteoglycans, fibroblasts there can be an inferiority of a connective tissue stroma of a uterus, and in particular an internal os of the cervix, leading to the CI.
Congenital defects of systemic connective tissue dysplasia are manifested by various stigmatization. Differentiated forms have pronounced genetic markers, undifferentiated forms are manifested by phenotopic markers.

Recently, there is no objection to progressive growth in populations of individuals with dysplastic phenotypes, which is considered as a result of anthropogenic factors $[8,9]$.

It is undeniable that undifferentiated connective tissue dysplasia plays an important role in asymptomatic shortening and dilation of the internal os of the cervix, which contributes to premature birth [9].

Timely detection of dysplastic stigma will improve the diagnosis and prediction of miscarriages on the background of CI, which is of great scientific and practical importance.

\section{THE AIM}

Study of the relationship between cervical insufficiency and dysplastic stigma in miscarriages.

\section{MATERIALS AND METHODS}

80 pregnant women were examined at 23-27 weeks of gestation. Group I included 40 pregnant women with the threat of premature birth, with recurrent spontaneous 


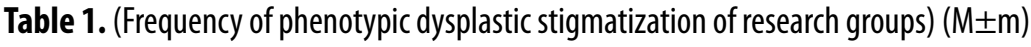

\begin{tabular}{|c|c|c|c|}
\hline \multirow[b]{2}{*}{ Phenotypic signs } & \multicolumn{3}{|c|}{ Groups of pregnant women } \\
\hline & $\begin{array}{r}\text { I group } \\
(n=40)\end{array}$ & $\begin{array}{c}\text { II group } \\
(n=20)\end{array}$ & $\begin{array}{l}\text { Control } \\
(n=20)\end{array}$ \\
\hline \multicolumn{4}{|c|}{ Ectodermal dysplastic stigmatization } \\
\hline subcutaneous venous plexus & $27,5 \pm 7,3$ & $15,0 \pm 8,2$ & $5,0 \pm 2,5$ \\
\hline blue sclera & $27,5 \pm 7,3$ & $15,0 \pm 8,2$ & - \\
\hline Visual impairment & $22,5 \pm 7,9$ & $15,0 \pm 8,2$ & - \\
\hline skin depigmentation & $22,5 \pm 7,9$ & $10,0 \pm 6,9$ & $5,0 \pm 2,5$ \\
\hline Hyperplasticity of the skin & $22,5 \pm 7,9$ & $15,0 \pm 8,2$ & - \\
\hline pale skin & $12,5 \pm 5,3$ & $10,0 \pm 6,9$ & - \\
\hline Hemangioma or telangiectasia & $7,5 \pm 4,2$ & $5,0 \pm 2,5$ & - \\
\hline \multicolumn{4}{|c|}{ Bone and skeletal dysplastic stigmatization } \\
\hline hypermobility of the joints & $72,5 \pm 7,1$ & $55,0 \pm 11,4$ & $20,0 \pm 9,2$ \\
\hline posture disorders & $57,5 \pm 7,9$ & $55,0 \pm 11,4$ & $20,0 \pm 9,2$ \\
\hline asthenic body structure & $52,5 \pm 7,2$ & $45,0 \pm 10,4$ & - \\
\hline sandal-shaped slit on the foot & $42,5 \pm 7,6$ & $10,0 \pm 6,9$ & - \\
\hline abnormalities in tooth growth & $15,0 \pm 5,7$ & $10,0 \pm 6,9$ & - \\
\hline \multicolumn{4}{|c|}{ Visceral dysplastic stigmatization } \\
\hline renal dysplasia & $77,5 \pm 6,9$ & $50,0 \pm 11,5$ & $5,0 \pm 3,2$ \\
\hline abnormal forms of the gallbladder & $65,0 \pm 7,6$ & $50,0 \pm 11,5$ & $5,0 \pm 3,2$ \\
\hline mitral valve prolapse & $52,5 \pm 7,9$ & $45,0 \pm 6,4$ & $10,6 \pm 4,9$ \\
\hline open oval hole & $17,5 \pm 6,1$ & $10,0 \pm 4,9$ & $2,0 \pm 1,2$ \\
\hline abnormal structure of the uterus & $7,5 \pm 3,4$ & $5,0 \pm 2,2$ & - \\
\hline umbilical hernia & $5,0 \pm 2,2$ & - & - \\
\hline
\end{tabular}

miscarriage and correction of cervical insufficiency (CI) by using pessary in the anamnesis. Group II consisted of 20 pregnant women with the threat of premature birth and correction of CI by using pessary without the burden of recurrent spontaneous miscarriage, the control group of 20 almost healthy pregnant women. To study the condition of the connective tissue, which included a clinical evaluation of dysplastic stigmatization, the total level of glycosaminoglycans in the serum and excretion of oxyproline in the urine were determined.

Statistical processing of the obtained data was performed using the programs "Microsoft Excel. When using medical and statistical analysis, the mean values and error $(\mathrm{M}+$ $\mathrm{m}$ ) were calculated, and the probability of the difference between the groups was determined by the Student's t-test.) All results were considered valid if $\mathrm{p}<0.01$ for the survey results and $\mathrm{p}<0.05$ in all other cases.

\section{RESULTS AND DISCUSSION}

The studies revealed phenotypic signs of dysplastic stigmatization (DS) in $39(97.5 \pm 2.5 \%)$ pregnant women of group I, in $18(90.0 \pm 6.9 \%)$ group II and in $4(20.0 \pm$ 9.2\%) control. Ectodermal dysplastic stigmas were represented by subcutaneous venous plexus, blue sclera, visual disturbances, depigmentation, pallor, skin hyperplasticity, hemangiomas or telangiectasia. and stretch marks.

Among the skeletal stigmas should be noted asthenic body structure, posture disorders, hypermobility of the joints, sandal-shaped slit on the foot, abnormalities in tooth growth. Visceral phenotypic signs of dysplastic stigmatization are represented by renal dysplasia, abnormal forms of the gallbladder, mitral valve prolapse, open oval hole $(\mathrm{d}=2.8 \pm 1.3 \mathrm{~mm})$, abnormal structure of the uterus, umbilical hernia.

The threshold of phenotypic stigmatization is significantly higher in groups I and II $(\mathrm{p}<0.05)$ than the control.

Among pregnant women of groups I and II there was an increased excretion per day of oxyproline, which amounted to $60.2 \pm 31.3$ and $57.0 \pm 23.1 \mathrm{mg} /$ day, respectively, against the background of reduced total serum glycosaminoglycans, which did not differ significantly in groups.

The results of studies revealed among pregnant women at risk of preterm birth in cervical insufficiency a high frequency of dysplastic stigmatization, which may indicate molecular genetic mechanisms of development, collagenopathy in this obstetric pathology. According to modern ideas, the signs of undifferentiated connective tissue dysplasia(UDCTD) are considered as a condition caused by inhibition of the activity of enzymes 
of various parts of the mitochondrial, the essence of which is reduced to "mitochondrial dysfunction"[10].

It should be noted that the etiopathogenesis of the premature birth in women with cervical insufficiency on the background of UDCTD for which there are a number of reasons, namely: genetic predisposition to collagenopathy, metabolic changes, chronic inflammation of the female genitals, micronutrient deficiency[11,12,13].

According to our data in the I group of pregnant women the asthenic type of the constitution coinciding with data of other authors prevailed.[14,15]. Among other manifestations of bone pathology, the most common were joint hypermobility, posture disorders and abnormalities in tooth growth, which can be closely related to both disorders of phosphorus-calcium metabolism and magnesium deficiency $[16,17,18]$.

Diagnostically significant markers of visceral manifestations of dysplasia were found: renal dysplasia, abnormal forms of the gallbladder, mitral valve prolapse, open oval hole, abnormal structure of the uterus. Along with visceral markers of dysplasia, ectodermal stigmas in the form of varicose veins, increased skin extensibility, depigmentation, the appearance of stretch marks and umbilical hernia during pregnancy were quite common in these patients. Among patients of groups I and II there was an increased excretion per day of oxyproline, which was $60.2 \pm 31.3$ and $57.0 \pm 23.1 \mathrm{mg}$ / day, respectively, against the background of reduced total levels of serum glycosaminoglycans, which did not differ significantly in groups, but significantly higher than the control group.

\section{CONCLUSIONS}

1. The most common gestational complication in women with UDCTD is the premature birth on the background of cervical insufficiency.

2. Improving existing and finding new diagnostic and therapeutic measures in pregnant women with UDCTD, will significantly reduce the risk of premature birth.

\section{REFERENCES}

1. Nechaeva G., Viktorova I., Druk I. Displaziya soedinitel'noj tkani: rasprostranennost', fenotipicheskie priznaki, assocziaczii s drugimi zabolevaniyami [Connective tissue dysplasia: prevalence, phenotypic features, associations with other diseases].Doctor.2006;1:19-23.(in Russian).

2. Holianovskyi 0.V. Mekhedko V.V. Halych I.D. Bachynska M.A. Istmiko-tservikalna nedostatnist i suchasni metody korektsii [Cervical insufficiency:Modern correction methods].Ukranian medical journal "Female doctor".2012;2:39-45. (in Ukrainian).

3. Vink J., Feltovich H. Cervical etiology of spontaneous preterm birth. Semin Fetal Neonatal Med. 2016; 21(2): 106-112. D0I: 10.1016/j. siny.2015.12.009.

4. Lukina T., Pavlov 0., Kozina E. Management of pregnant women with undifferentiated connective tissue dysplasia. Journal of New Medical Technologies eJournal. 2015; 9(4). D0l: 10.12737/16165.

5. Dietz H. P., Steensma A. B. Which women are most affected by delivery related changes in pelvic organ mobility?: Eur J Obstet Gynecol Reprod Biol. 2003 Nov 10;111(1):15-8. doi: 10.1016/s0301-2115(03)00155-6.
6. Lukianenko N.S. Mistse nedyferentsiiovanoi dysplazii spoluchnoi tkanyny v patolohii dytiachoho viku [The place of undifferentiated connective tissue dysplasia in the pathology of childhood]. Child Health.2015;2(61):80-85. (in Ukrainian).

7. Shcherbyna M.0. Markery rozpadu kolahenu v rozvytku prolapsu henitalii u zhinok v perymenopauzi [Markers of collagen breakdown in the development of genital prolapse in perimenopausal women]. Current issues of pediatrics, obstetrics and gynecology.2016;2:111-114. (in Ukrainian).

8. Gurbanova S.R. Rol nedifferenczirovannoj displazii soedinitel'noj tkani v patogeneze istmiko-czervikal' noj nedostatochnosti [The role of undifferentiated connective tissue dysplasia in the pathogenesis of cervical insufficiency]. Materials of the 14th Congress of Obstetricians and Gynecologists of Russia.2008;63-64.(in Russian).

9. Prokip U.Ye.Udoskonalennia diahnostychno-terapevtychnykh zakhodiv pry idiopatychnii istmiko-tservikalnii nedostatnosti [Improvement of diagnostic and therapeutic measures in idiopathic cervical insufficiency]. 2016: 20 p. (in Ukrainian).

10. Torshin I.Yu., Gromova 0.A. Molekulyarny`e mekhanizmy`vozdejstviya magniya na displaziyu soedinitel' noj tkani [Connective tissue dysplasia, cell biology and molecular mechanisms of magnesium action]. Russian medical journal.2008; 16(4):230-238.(in Russian).

11. Abrahamovych 0. 0. Faiura 0. P. Abrahamovych U. 0. Komorbidnist: suchasnyi pohliad na problemu; klacyfikatsiia (povidomlennia pershe) [ Comorbidity: a modern view of the problem; classification (first message)].Lviv Clinical Bulletin. 2015; 4 (12): 56-64. (in Ukrainian).

12. Magomedov S., Zhabchenko I., Oleshko V. et al. Features of connective tissue metabolism and microelements in blood serum of pregnant women with cervical insufficiency.eureka:healthsciences. 2018;6:30-36. D0l:http://eu-jr.eu/health/article/view/784.

13. Nikitin V. A., Vasil'eva L. V., Tolsty 'kh E. M. et al. Rol sistemnogo vospaleniya v razvitii komorbidnosti pri khronicheskoj obstruktivnoj bolezni legkikh [The role of systemic inflammation in the development of comorbidity in chronic obstructive pulmonary disease]. Tuberculosis and lung disease journal. 2017;6(95):61-65(in Russian).

14. Shibel'gut N.M., Zakharov I.S., Mozes V.G. Techenie beremennosti i iskhody' rodov u zhenshhin s nedifferenczirovanny` mi formami displazii soedinitel' noj tkani[Clinical implications of phenotypic and biochemical manifestations of undifferentiated forms of connective tissue dysplasia in pregnant women].Medicine in Kuzbass. 2009;8(6):28-32 (in Russian).

15. Smirnova T.L., Gerasimova L.I. Features of clinical manifestations of the syndrome of undifferentiated connective tissue dysplasia. Doctor.Ru. 2018;8(152):40-44. D0I: 10.31550/1727-2378-2018-152-8-40-44.

16. Smirnova T.L., Gerasimova L.I., Sidorov A.E. et al. Osobennosti techeniya beremennosti i rodov u zhenshhin s sindromom nedifferenczirovannoj displazii soedinitel' noj tkani [Features of the course of pregnancy and childbirth in women with the syndrome of undifferentiated connective tissue dysplasia]. Practical medicine. 2018;16(6):39-44. (in Russian).

17. Domnitskaia T.M., D'iachenko A.V., Kupriianova 0.0. et al. Klinicheskoe znachenie primeneniya magniya orotata u podrostkov s sindromom displazii soedinitel' noj tkani serdcza [Clinical value of the use of magnesium orotate in adolescents with syndrome of cardiac connective tissue dysplasia]. Cardiology. 2005; 3(45):76-81. (in Ukrainian).

18. Shvarts H. Ya. Vitamin D, D-gormon i al' fakal' czidiol: mediczinskie, molekulyarno-biologicheskie i farmakologicheskie aspekty [Vitamin D, D-hormone and alfacalcidol: medical, molecular biological and pharmacological aspects].Ukrainian rheumatological magazine. 2009;3:63-69. (in Ukrainian). 


\section{ORCID and contributionship:}

Tunzala V. Ibadova : 0000-0003-0113-8995 ${ }^{A, C}$

Vasyl V. Maliar: 0000-0001-9950-5014 ${ }^{B, D, F}$

Vitalii V. Maliar: 0000-0002-1310-535X ${ }^{E, F}$

Volodymyr V. Maliar: 0000-0003-0350-3255 D,F

\section{Conflict of interest:}

The Authors declare no conflict of interest.

\section{CORRESPONDING AUTHOR}

Tunzala V. Ibadova

Uzhhorod national University

1 Narodna sqr., 88000 Uzhhorod, Ukraine

tel: +380506303138

e-mail: tunzala.ibadova@uzhnu.edu.ua

Received: 17.11 .2020

Accepted: 04.03.2021

A - Work concept and design, B - Data collection and analysis, C - Responsibility for statistical analysis,

D-Writing the article, $\mathbf{E}$-Critical review, $\mathbf{F}$ - Final approval of the article 